\title{
Evolução e desempenho do mercado externo das regiões brasileiras produtoras de produtos metal mecânicos
}

\author{
Lucas Teixeira Araújo ${ }^{1}$ \\ Jorge Nogueira de Paiva Britto ${ }^{2}$
}

\section{Resumo}

O presente trabalho analisa a evolução recente das pautas de exportação das microrregiões especializadas em metal mecânica no Brasil. Para tanto, foram observado o volume total das exportações, a distribuição dos destinos das vendas dos produtos desse complexo industrial bem como a diversificação dos mercados visto ao nível da diferenciação produtiva. Foi possível observar que apesar de todos os problemas que vem passando a indústria brasileira, esse conjunto de setores conseguiu manter certa competitividade em alguns produtos. Contudo, o cenário futuro não se apresenta tão otimista e políticas devem ser pensadas com o intuito de proteger e diversificar tais setores estratégicos.

Palavras Chaves: Metal mecânica, pauta de exportação, competitividade

\section{Abstract}

This paper analyzes the recent evolution of export list in Brazilian microregions context of metal working specialization. Therefore, it was observed the total of exportations, export destinations by countries as well the diversifications of markets seen at the level of productive differentiation. It was possible to find that despite all actual problems in national industries, this set of sectors maintain international competitiveness in some products. However, the future scenario is not so optimistic and policies should be designed to protect and diversify such strategic sectors.

Key words: Metal working, export products, competitiviness

Área Temática: Área 2 - Comércio internacional, cadeias de valor e internacionalização.

JEL: F1, F6, O2

\footnotetext{
${ }^{1}$ Aluno de doutorado do programa de pós-graduação em economia da Universidade Federal Fluminense e bolsista CAPES.

${ }^{2}$ Professor doutor do curso de pós-graduação de economia da Universidade Federal Fluminense.
} 


\section{Introdução}

O artigo tem como objetivo avaliar a evolução do comércio exterior das microrregiões brasileiras especializadas em produtos do complexo metal mecânicos entre 2006, 2010, 2013 e 2016. Esse complexo é definido como o conjunto de indústrias que processam e utilizam materiais metálicos para a produção de insumos industriais ou produtos para o mercado final que vão desde produtos de metal para uso diverso até produção de veículos automotores, embarcações de grande porte e aeronaves. Tais setores são significativamente diferentes, porém, interligados em uma cadeia de produção e de geração de valor, compartilhando uma base tecnológica similar e complementar para a produção. Esse complexo sempre manteve uma posição estratégica na indústria mundial. A indústria de trens e locomotivas, por exemplo, foi uma das mais importantes na segunda metade do século XIX (PEREZ, 2010). Já no início do século XX o mundo experimentou o advento da indústria automotiva com as inovações organizacionais de Henry Ford (WOWACK et all, 1990). Deve-se considerar também a indústria de aeronaves, uma das mais dinâmicas nas economias mundiais (ROSENBERG, 2009). No âmbito dessa indústria, o processo de transformação de insumos básicos da indústria também passa por modificações sistemáticas como demonstra Treado (2013) para o caso da formação de um sistema de inovação e produção de serviços tecnológicos em aços na região de Pittsburgh nos Estados Unidos. Mais recentemente, este complexo constitui um dos exemplos mais paradigmáticos dos impactos relacionados à consolidação de Cadeias Globais de Valor (CVCs), com impactos importantes em termos da inserção de países em desenvolvimento (ALBUQUERQUE, 2011). Nesse contexto, o estudo desse complexo é de suma importância para entender o desenvolvimento da indústria de um país.

O trabalho assume a hipótese desenvolvida em Hausmann, Hwang e Rodrick (2007), segundo a qual se uma região exporta determinado produto ela provavelmente conseguiu desenvolver capacidades internacionais competitivas para tal mercadoria. Ou seja, nessa região seria possível encontrar trabalhadores, empresas e instituições necessárias para que o produto seja fabricado mesmo que a região seja uma importadora líquida do produto em questão. Assim, mapeando os produtos exportados por cada localidade selecionada, seria possível elaborar um "mapa" de possibilidades de crescimento e integração de diferentes indústrias, de forma a subsidiar a construção de políticas públicas de fomento. É com o intuito de avançar no sentido de contribuir na caracterização desse "mapa" de possibilidades que se estrutura a análise desenvolvida ao longo do artigo.

$\mathrm{O}$ artigo tem como objetivo avaliar a evolução do comércio exterior das regiões brasileiras produtoras de produtos metal mecânicos. No estudo, define-se como complexo metal mecânico o conjunto de indústrias que processam e utilizam materiais metálicos para a produção de insumos industriais ou produtos para o mercado final. Nesse complexo, se encontram setores significativamente diferentes, porém, interligados em uma cadeia de produção e de geração de valor. Para definir a cobertura geográfica do complexo metal mecânico, o trabalho propõe uma adaptação realizada a partir da definição que fundamentou o relatório do estudo "Análise Exploratória do Conjunto de Informações na Base de Dados dos Arranjos Produtivos Locais Brasileiros" (2016), elaborado para o Grupo de Estudos Permanentes de Arranjos Produtivos Locais (GTP-APL) do Ministério do Desenvolvimento, Indústria e Comércio Exterior (MDIC), cujo objetivo era mapear e caracterizar núcleos de atividade (municípios) onde existiria evidências da presença de APLs no Brasil.

A definição dos setores foi realizada pela classificação CNAE 2.0, realizando-se uma seleção de atividades vinculadas ao complexo metal mecânico a partir dos empregos existentes das microrregiões brasileiras no ano de 2013. De maneira a caracterizar o potencial exportador dessas microrregiões, o artigo seguirá com outras cinco seções. Na seção seguinte apresenta-se uma breve discussão do papel das exportações para expressar a capacidade de produção de um determinado local e a sua competitividade. $\mathrm{Na}$ terceira seção será discutida a metodologia do trabalho em que são colocadas a maneira como foram selecionadas as microrregiões produtoras do complexo metal mecânico e os índices que serão utilizados na análise. A terceira seção se ocupa de uma discussão geral da balança comercial do complexo metal mecânico brasileira e a quarta seção faz uma análise mais específica da pauta de exportação das localidades selecionadas. Na última seção descrevem-se algumas conclusões possíveis da análise realizada. 


\section{Referencial teórico}

A inserção de países e setores nos fluxos de comércio exterior sempre foi motivo de um debate aberto na economia sobre as potencialidades da especialização produtiva como elemento para aceleração de processos de desenvolvimento e catching-up $\mathrm{Na}$ teoria tradicional de Ricardo bem como na sua evolução pelo modelo de Heckscher-Ohlin, o país deveria se especializar dada a sua dotação inicial de fatores e assim garantir os ganhos advindos da maior eficiência através do comércio exterior (KRUGMAN, OBSTFELD e MELITZ 2014). Esses pressupostos foram duramente criticados por Prebisch (2000) a partir da constatação de que a elasticidade-renda dos países produtores de bens industrializados seria maior que nos países produtores de bens primários e isso teria importantes desdobramentos para o processo de desenvolvimento econômico. Os países industrializados teriam capacidades de manter níveis mais homogêneos de produtividade entre seus setores enquanto aqueles de base primária teriam comportamento mais heterogêneo. Tal fenômeno poderia ser associado às dificuldades e assimetrias encontradas na difusão tecnológica entre as diversas regiões (CIMOLI, PORCILE e SILVA, 2012). Assim, seria possível descrever um esquema em que o mundo se dividiria entre um centro dinâmico e desenvolvido, por um lado, e uma periferia atrasada e subdesenvolvida pelo outro. Enquanto na primeira ocorrem taxas de crescimento elevadas com grande força do espraiamento das inovações tecnológicas, na segunda se observa baixas e irregulares taxas de crescimento com a inovação concentrada nos setores de produção voltada para o mercado externo (VILAÇA, 2017). Nessa última, seria particularmente difícil manter taxas de crescimento elevadas concomitantemente a um equilíbrio no balanço de pagamentos e a economia apresentaria desequilíbrios históricos (AMARAL, FREITAS e CASTILHO, 2017). A economia pós-keynesiana desenvolveu a Lei de Thirwall na qual a taxa de crescimento de longo prazo se dá pela taxa de crescimento das exportações dividido pela elasticidade renda das importações (THIRWALL, 2002).

Ainda hoje a discussão sobre qual modelo de comércio os países devem tomar como referência para impulsionar seu processo de desenvolvimento continua em voga. Em uma contribuição para esse debate, Hausmann, Hwang e Rodrick (2007), por exemplo, calcularam um indicador para a renda per capta média associada à geração de diferentes produtos e perceberam que existe uma considerável diferença dentre eles. Em especial, seria possível observar que os produtos não têm uma distribuição aleatória e aqueles que geram maior retorno se localizam em regiões historicamente mais industrializadas. Nessa linha, Hidalgo et. all (2007) desenvolveram a teoria dos "espaços de produtos" em que associam um produto a outro de acordo com a capacidade de dois países distintos de exportá-los por meio de um indicador de vantagens comparativas reveladas. Por fim, eles desenvolveram o que foi chamado de "índice de complexidade" que hierarquiza a posição de um país de acordo com as interconexões dos produtos que ele produz (HIDALGO e HAUSMANN, 2009). Sendo assim, alguns produtos poderiam ser demandados em países diferentes e o país produtor de tal mercadoria não teria um poder de mercado efetivo, enquanto isso, outros produtos seriam oferecidos por um número específico de países, que fora do mercado gerariam uma escassez relativa. Alguns testes foram feitos e demonstraram que o indicador pode ser considerado uma proxy interessante para a renda per capta dos países ${ }^{3}$.

Outra abordagem do papel do mercado exterior foi desenvolvida em Lall (2000). Esse autor desenvolveu uma classificação dos produtos baseada num sistema harmônico de 4 dígitos da ISIC, em que se poderia diferenciar as mercadorias como produtos primários, manufaturas baseadas em recursos naturais, manufaturas de baixa tecnologia, manufaturas de média tecnologia e manufaturas de alta tecnologia. $\mathrm{O}$ autor encontrou um padrão em que as cestas de exportação dos países de mais alta renda

\footnotetext{
${ }^{3}$ Esse indicador recebeu uma série de críticas apesar de constituir um esforço louvável no que diz respeito a encontrar um retrato do comércio exterior em um determinado ano. Dentre essas críticas, pode-se observar o que foi dito por Lederman e Maloney (2010) que a classificação dos produtos nem sempre reflete o que o produto de fato representa. Isso seria evidente na comparação da indústria de computadores que na China é bem mais simples que nos Estados Unidos. A segunda crítica foi realizada pelos próprios autores que caso reduzissem o trashhold do corte das vantagens comparativas reveladas, os países industrializados se tornariam bem mais complexo (HIDALGO e HAUSMANN, 2009). Ainda cabe notar que o índice se baseia em valores exportados sendo que uma grande mudança nos preços de uma quantidade pequena de produtos poderia gerar uma mudança significativa do índice para determinados países especializados sem que isso mantivesse qualquer relação com uma mudança estrutural.
} 
eram compostas, em sua maioria, de produtos das duas camadas mais altas de tecnologia. A partir dessa classificação, Schteingart (2015) desenvolveu um índice para medir o nível de sofisticação da pauta dos países. Esse índice, juntamente com uma medida da intensidade tecnológica dada pelas atividades de P\&D e patenteamento, possibilitou a construção de um espaço que dispunha os países de acordo com seu grau de desenvolvimento. Assim, países com uma pauta de exportação com maior intensidade tecnológica e maior disponibilidade de serviços tecnológicos estariam em uma posição melhor que os demais quando se observa suas rendas per captas ${ }^{4}$. Tal esquema possibilitou observar a evolução dos países a partir desse par de índices, a partir dos quais foi possível captar o catching up sul coreano bem como as trajetórias menos regulares dos países latino-americanos.

Quanto o desenvolvimento histórico da América latina, Katz (2009) demonstra que no, final da década de 1970 e início da década de 1980, uma boa parte da mudança estrutural já havia ocorrido nos maiores países latino-americanos. ${ }^{5}$ Isso seria evidenciado não só pela pauta de exportação dessas localidades que seriam compostas de uma importante fatia de produtos industrializados, como também pela capacidade que esses países adquiriram em exportar máquinas, equipamentos e módulos industriais. Contudo, o autor chama a atenção que essas exportações se restringiam a países da própria América Latina e era formada, em sua maioria por empresas estrangeiras em um processo de ampliação estratégica de sua atuação na região. Tal dificuldade de penetrar nos mercados mais dinâmicos com produtos sofisticados poderia estar relacionada com a forma escolhida pelos países latino-americanos de se industrializarem. Conforme ressaltado por Fanjzylber (1979), a industrialização da periferia latino americana teria ocorrido, fundamentalmente, com base em maquinário importados por grandes companhias aqui instaladas com um diferencial tecnológico considerável em relação ao equipamento empregado pelas mesmas companhias em seus países de origem. A periferia teria cumprido um papel de reutilização de uma massa de capital já descartável para os padrões de desenvolvimento do centro. Ademais, esse tipo de processo não permitiria que se constitua uma trajetória de aprendizado consistente de longo prazo, e, apesar de inserir um aumento na taxa de lucro no instante da industrialização, essa vai reduzindo à medida que a indústria se torna cada vez mais obsoleta.

A partir da década de 1980 o modelo de substituição de importações entrou em crise por motivos diversos como o alto endividamento das economias periféricas e a incapacidade de rolar essa dívida por mecanismos tradicionais, bem como por um crescimento de outros países que passaram a tomar fatias interessantes das exportações latino-americanas bem como das brasileiras. A saída para esse movimento se deu pela abertura comercial e de capitais ocorridas em um período de eclosão das cadeias globais de valor. Essas últimas são marcadas por um forte aumento do comércio interfirmas e uma reorganização dos processos internacionais de divisão do trabalho. A fragmentação do processo produtivo está associada à natureza da base técnica de cada indústria, ocorrendo mais frequentemente em processos produtivos modulares (separáveis por etapas), característicos da indústria de montagem - como aeronáutica, automobilística e material eletrônico - diferentemente das indústrias de processos contínuos - como química e siderurgia - que requerem tecnologia e principalmente, economia de escala. Como fatores motivadores desse processo, destaca-se a evolução tecnológica dessas indústrias, que possibilita a separação do processo produtivo em diferentes etapas, a redução dos custos de transporte e de transação (devido à liberalização comercial e desregulamentação de mercados) e a realização de mudanças nas estratégias de empresas multinacionais $(\mathrm{EMN})$, contemplando a subcontratação e/ou instalação de filiais em diferentes países para aproveitamento das vantagens comparativas dos diversos países. A produção de um bem final seria fragmentada de acordo com as vantagens comparativas e competitivas de cada país e o processo produtivo seria composto por parcelas de produtos com diferentes conteúdos tecnológicos, dividido de acordo com a eficiência relativa de cada país envolvido no processo. O crescimento das transações em cadeias globais de valor, bem como a maior complexidade de suas redes, implica um aprofundamento da internacionalização e uma intensificação dos fluxos comerciais, sejam aqueles que

\footnotetext{
${ }^{4}$ Nova Zelândia, Austrália e Noruega se constituíram como exceções nesse esquema criado e foram chamados de países inovadores primarizados. O autor também observou que havia um grupo de países que com uma pauta sofisticada porém, poderiam ser classificados como montadores. Assim, o modo de como os produtos são produzidos é tão importante quanto quais deles são produzidos.

${ }^{5} \mathrm{O}$ autor considera Brasil, México e Argentina nesse grupo.
} 
envolvem transações intra-firma, sejam aqueles vinculados a redes de fornecimento que refletem processo de "outsourcing" e "offshoring". Tal fenômeno foi ainda mais reforçado na década de 2000 com o crescimento vertiginoso da economia chinesa e a periferia experimentou um crescimento elevado da demanda de seus produtos tradicionais para alimentar a industrialização em curso no país asiático. Assim, o Brasil apresentou um aumento nos níveis de exportações acima da média anual entre 1995 e 2011 que foi revertido a partir de 2012. AMARAL, FREITAS e CASTILHO (2017) observaram que a partir de 2012 a China passa a ocupar os mercados tradicionais dos produtos manufaturados brasileiros na América Latina bem como passa a atender cada vez mais a demanda interna brasileira por novos produtos industrializados.

\section{Metodologia}

\section{Escolha das regiões da análise}

A seleção dos setores será feita a partir da metodologia sugerida na pesquisa "Análise Exploratória do Conjunto de Informações na Base de Dados dos Arranjos Produtivos Locais Brasileiros" (2016) realizada sobre para o Ministério do Desenvolvimento, Indústria e Comércio exterior. Após a determinação das atividades setoriais que compões o complexo metal mecânico, buscou-se selecionar a partir das microrregiões do IBGE, localidades que tenham quantidades significativas de emprego para esse complexo. De modo a caracterizar as microrregiões com potencial de especialização produtiva em atividades do complexo metal mecânico, realizou-se uma seleção a partir dos empregos existentes das microrregiões brasileiras no ano de 2013, considerando-se quatro critérios: (i) seleção de todas as microrregiões com quociente de localização maior que 3 para as subclasses da produção préselecionadas 6 ; (ii) seleção das microrregiões com QL entre 0,8 e 3 e um pessoal ocupado de pelo menos 4.000 nas subclasses selecionadas; (iii) seleção das microrregiões que não atendem a nenhum dos critérios acima, porém tenha pelo menos um empregado em no mínimo a metade das subclasses pré-selecionadas critério de diversificação; e, (iv) procurou-se ainda considerar se haveria alguma microrregião que apresentasse evolução em algum dos indicadores após o ano de 2013, ou seja, para o período de crise da economia brasileira entre 2014 e 2016. Os critérios levaram a seleção das microrregiões que são apresentadas no quadro 1.

Essa distribuição territorial não apresentou diferença significativa quando comparada com a distribuição total da indústria brasileira. Como foi demonstrado por Diniz (1993), ocorreu um movimento de desconcentração nas décadas de 1970 e 1980 em que o a região da cidade de São Paulo foi diminuindo o seu percentual no total na indústria, em simultâneo ao crescimento de outras localidades. Contudo, isso ocorreu em uma região que ficou conhecida como "polígono" que se limitaria ao Centro-Sul brasileiro. De todas as 71 regiões selecionadas, apenas 9 situam-se fora da área do polígono. Esse fato demonstra quão difícil é a promoção de políticas de desenvolvimento autônomas e em polos distantes do centro comercial brasileiro, que continua sendo São Paulo.

\section{Apresentação dos dados e construção dos indicadores}

A apresentação dos dados será feita para três cortes em diferentes dimensões. O primeiro deles se encarregará da distribuição das exportações entre as 71 microrregiões selecionadas elencando aquelas com maior número de vendas para o exterior. O segundo ponto conta com uma abordagem dos principais destinos em termos de países para onde os produtos brasileiros são vendidos. Por fim, será feita uma abordagem quanto à diversificação ao nível dos produtos classificados pelo NCM/SH4 para as localidades. Para cada um desses cortes foram avaliadas as microrregiões mais importantes por meio de quadros em que foram selecionados e contados os indivíduos que responderiam por pelo menos $50 \%$ do valor total a ser investigado. Ainda para a questão da distribuição dos produtos será apresentado mapas de calor (heat maps) referentes a cada uma dos períodos escolhidos. Esses permitem que sejam visualizadas evoluções gerais e regionais nos padrões das exportações.

\footnotetext{
6 As subclasses pré-selecionadas foram retiradas do Produto 6 e foram escolhidas com base nas divisões da CNAEs , 24(metalurgia), 25 (produtos de metal), 27 (Máquinas e aparelhos elétricos), 28 (Fabricação de máquinas e equipamentos), 29 (Fabricação de veículos automotores) e 30 (outros materiais de transporte).
} 
Quadro 1: Microrregiões selecionadas

\begin{tabular}{|c|c|c|}
\hline $\begin{array}{l}\text { Região } \\
\text { Natural }\end{array}$ & Estado (número de localidades) & Microrregião \\
\hline Norte & Amazonas (2) & Manaus, Rio Preto da Eva \\
\hline \multirow{3}{*}{ Nordeste } & Ceará (1) & Fortaleza \\
\hline & Pernambuco (3) & Mata Setentrional Pernambucana, Recife, Suape \\
\hline & Bahia (1) & Salvador \\
\hline \multirow[b]{4}{*}{ Sudeste } & Minas Gerais (10) & $\begin{array}{l}\text { Bocaiúva, Sete Lagoas, Belo Horizonte, Itaguara, Conselheiro Lafaiete, } \\
\text { Ipatinga, Divinópolis, Varginha, Pouso Alegre, Itajubá }\end{array}$ \\
\hline & Espírito Santo (1) & Vitória \\
\hline & Rio de Janeiro (4) & $\begin{array}{l}\text { Nova Friburgo, Vale do Paraíba Fluminense, Baía de Ilha Grande, Rio de } \\
\text { Janiro }\end{array}$ \\
\hline & São Paulo (26) & $\begin{array}{l}\text { São José do Rio Preto, Catanduva, Jaboticabal, Ribeirão Preto, Jaú, } \\
\text { Botucatu, Araraquara, São Carlos, Limeira, Piracicaba, São João da Boa } \\
\text { Vista, Moji Mirim, Campinas, Marília, Tatuí, Sorocaba, Jundiaí, } \\
\text { Bragança Paulista, São José dos Campos, Guaratinguetá, } \\
\text { Paraibuna/Paraitinga, Osasco, Guarulhos, Itapecerica da Serra, São } \\
\text { Paulo, Mogi das Cruzes }\end{array}$ \\
\hline \multirow{3}{*}{ Sul } & Paraná (5) & Maringá, Londrina, Ponta Grossa, Cascavel, Curitiba \\
\hline & Santa Catarina (7) & Chapecó, Joinville, Rio do Sul, Blumenau, Itajaí, Tubarão, Criciúma \\
\hline & Rio Grande do Sul (9) & $\begin{array}{l}\text { Santa Rosa, Erechim, Ijuí, Passo Fundo, Não-Me-Toque, Caxias do Sul, } \\
\text { Santa Cruz do Sul, Porto Alegre, Litoral Lagunar }\end{array}$ \\
\hline Centro Oeste & Goiás (2) & Goiânia, Catalão \\
\hline
\end{tabular}

Fonte: elaboração própria

O trabalho utilizará alguns indicadores para demonstrar o comportamento das exportações nas microrregiões ${ }^{7}$ além de trabalhar com os valores absolutos dessa medida. Um desses indicadores será o índice de preenchimento que foi adaptado a partir do trabalho de Ribeiro et. all (2010) e poderá ser resumido na seguinte fórmula:

$$
P(M)=\sum_{i=1}^{n} \sum_{j=1}^{m} \frac{\delta_{i j}}{n * m}
$$

Em que M é o valor do indicador. $\delta_{\mathrm{ij}}=0$ se a componente ij da matriz for zero e $\delta_{\mathrm{ij}}=1$ se a componente for diferente de zero. $n$ representa os elementos das i linhas e $m$ os elementos das $\mathrm{j}$ colunas. As linhas sempre representarão as microrregiões e as colunas serão ora representadas pelos países de destino e ora pelos produtos de acordo com a classificação NCM/SH4. Quando o cálculo for para cada microrregião, o indicador se reduzirá para apenas o somatório das m colunas para uma linha $\mathrm{n}$ específica.

O segundo indicador a ser utilizado é o índice Herfindahl-Hirschman para cada uma das linhas das matrizes sugeridas acima como sugerido em Resende e Boff (2013). Esse pode ser descrito pela equação:

$$
H H_{i}=\sum_{j=1}^{m} h_{j}
$$

Em que h representa a participação ao quadrado do elemento j na composição da pauta de exportação da microrregião i. $\mathrm{HH}_{\mathrm{i}}$ é o valor do indicador para cada localidade.

\footnotetext{
${ }^{7}$ Cabe ressaltar que não serão levadas em consideração as importações e as balanças comerciais microrregionais já que essas têm problemas. Boa parte das importações é realizada por importadoras localizadas em uma microrregião e depois vendidas para outras microrregiões como vendas locais. Assim, não são contabilizadas como comércio exterior na região final. $\mathrm{O}$ mesmo pode acontecer com as exportações, entretanto, esse caminho é muito mais raro do que no caso das importações já que a atuação de exportadoras é menor que a atuação de importadoras.
} 
Para finalizar, será utilizado um indicador para determinar a variação estrutural entre os períodos analisados que é a correlação entre as matrizes de cada período que será apresentado por uma matriz de correlações.

\section{A balança comercial da metalmecânica}

A balança comercial do complexo metal mecânico foi construída com os dados do portal de comércio exterior do Brasil, COMEXSTAT. ${ }^{8}$ Os códigos NCM a 4 dígito selecionados tiveram como correspondência as CNAEs 2.0 já selecionadas e a conversão se deu a partir da tabela fornecida pelo IBGE no portal CONCLA ${ }^{9}$. Os dados para o setor metal mecânico como um todo para 2006, 2010, 2013 e 2016 podem ser vistos na Figura 1 abaixo:

\section{Figura 1 - Evolução da balança comercial da metal mecânica em milhões de dólares}

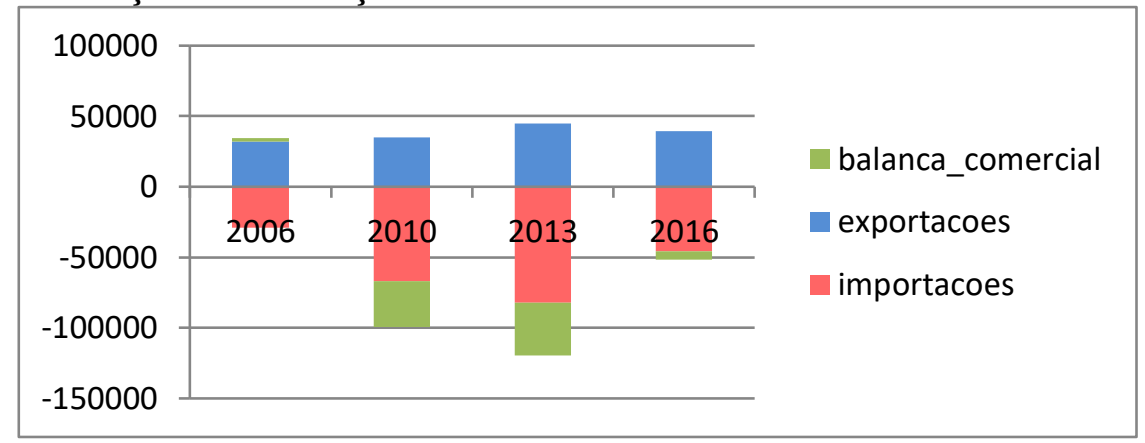

Fonte: Elaboração própria com base nos dados do Comexstat

As importações apresentaram uma volatilidade bem maior que as exportações e o visível aumento do déficit se deve a esse fenômeno. Em 2006, ocorreu um pequeno superávit de pouco menos de 3 bilhões de dólares que foi revertido para um déficit em 2010 pra 32 bilhões. Esse déficit foi ainda mais alto no ano de 2013, chegando a 37 bilhões, e, por fim, recuou para pouco mais de 6 bilhões em 2016. É perceptível como o aumento das importações corresponde ao período de crescimento da economia brasileira e como nesse mesmo período houve um impulso da demanda interna via investimento nacional. Isso gerou uma procura maior de produtos do complexo metal mecânico que não podendo ser atingida pelo mercado interno brasileiro veio pro meio de importações. Isso evidencia a necessidade de desenvolver esse setor para que quando ocorrer um aumento do investimento o mercado interno tenha condições de responder e mitigar o vazamento das rendas para o mercado.

O resultado apresentado acima pode ser decomposto em cada ano para as divisões da CNAE 2.0 descritas anteriormente nesse trabalho. Essa decomposição pode ser vista na figura 2 abaixo.

Para 2006, é possível notar que das seis divisões analisadas no trabalho, apenas máquinas (Divisão-28) e automotores (Divisão-29) obtiveram déficits. A divisão 24 (metalurgia) apresentou o maior superávit que chegou a mais de 11 bilhões de dólares. Já em 2010, apenas a metalurgia mantinha superávit. Observando o comportamento das exportações, nota-se que obtiveram um pequeno aumento saindo de 31,8 bilhões de dólares em 2006 para 34,8 bilhões de dólares em 2010. Dessa forma, a reversão da balança comercial do complexo para um déficit se deveu quase que totalmente a um aumento nas importações. Essa era de 29,1 bilhões para 2006 e passou para 67,0 bilhões em 2010, sendo o aumento das importações de máquinas e equipamentos o maior responsável para esse movimento.

\footnotetext{
8 O COMEXSTAT substituiu o antigo portal de consultas ALICEWEB e pode ser acessado no link: http://comexstat.mdic.gov.br/pt/home.

9 A tabela de conversão pode ser encontrada no link: https://concla.ibge.gov.br/classificacoes/correspondencias/atividadeseconomicas.
} 
Figura 2a - Balança Comercial 2006 em milhões de dólares

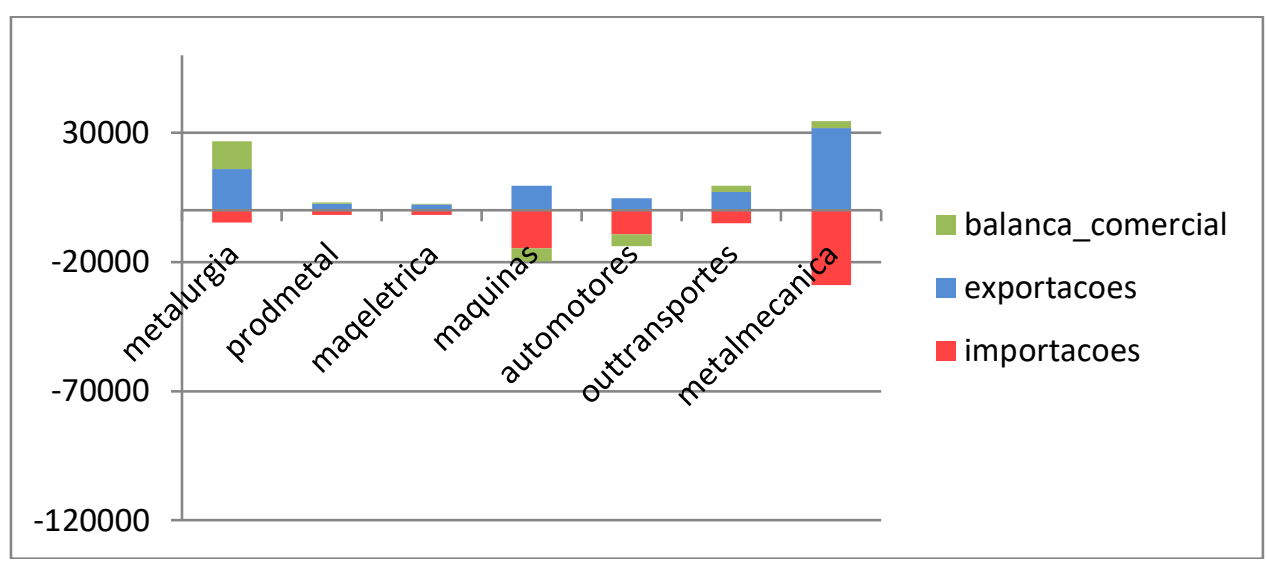

Figura 2b - Balança comercial de 2010

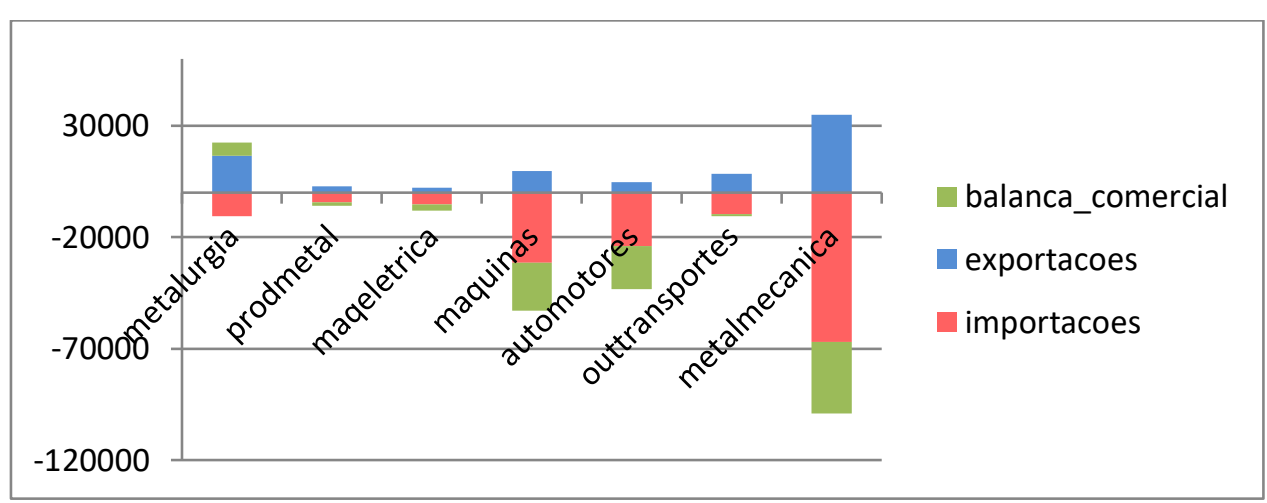

Figura 2c - Balança comercial 2013 em milhões de dólares

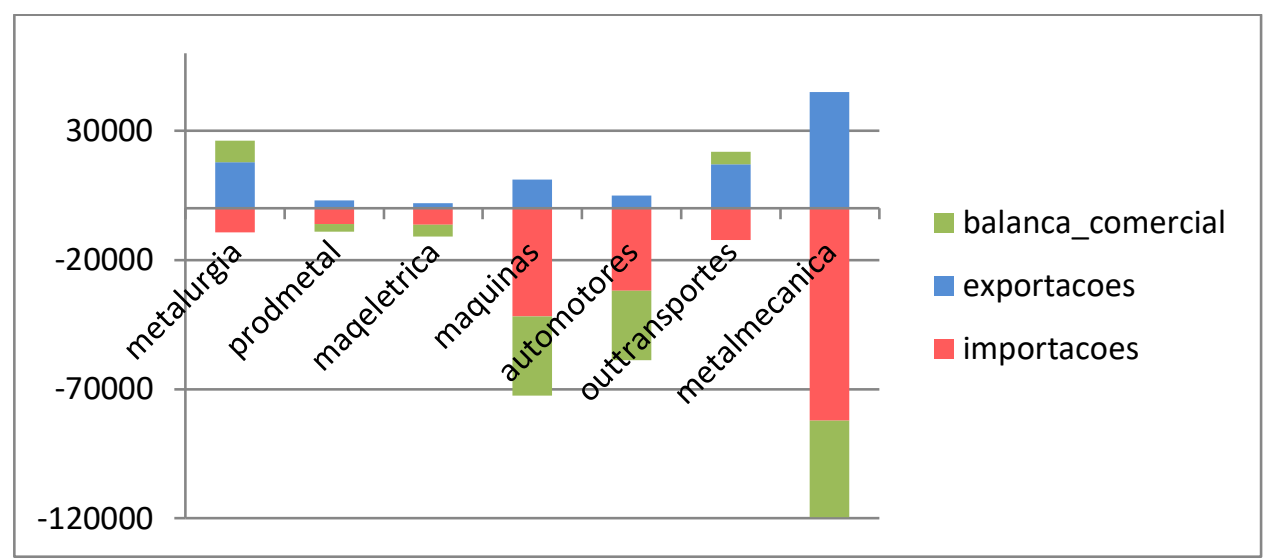

Figura 2d - Balança comercial 2016

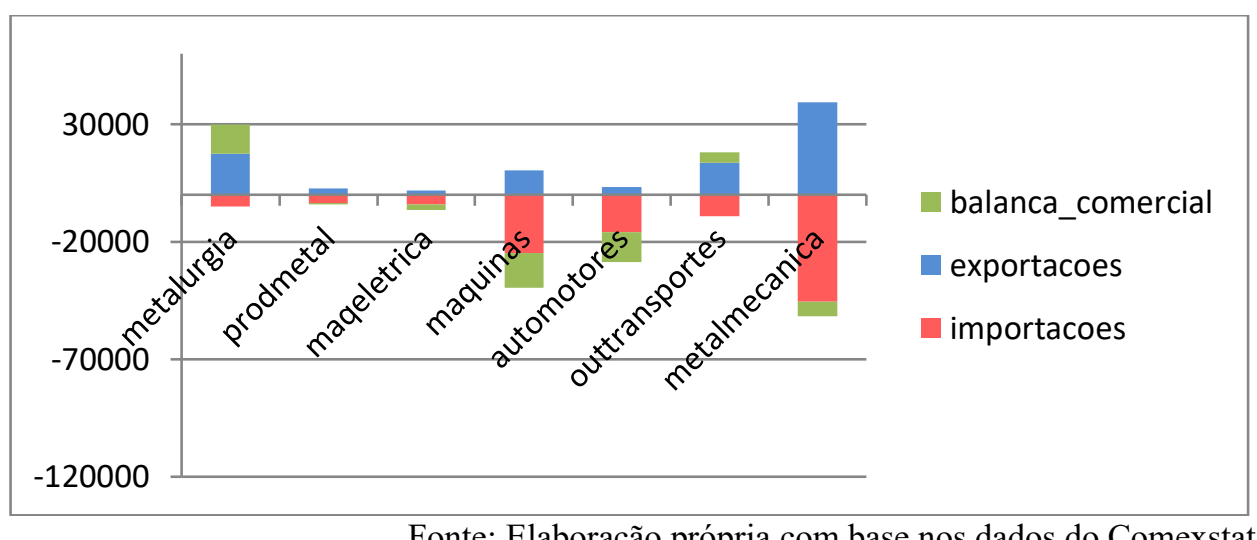


As balanças comerciais de 2010 e 2013 são estruturalmente parecidas, entretanto, o déficit se agravou e alcançou 37,2 bilhões nesse último ano. A divisão de metalurgia diminuiu suas importações em $11,1 \%$ e foi a única que apresentou esse comportamento. Já os produtos de metal foi aquela que mais aumentou com 38,6\%. Quanto às exportações, o destaque vai para a divisão de outros materiais de transporte que obteve um crescimento de $103,8 \%$ revertendo um déficit encontrado no período anterior para um pequeno superávit. Por fim, em 2016, observa-se que a recessão brasileira refletiu consideravelmente no comércio exterior desse setor em que todas as divisões reduziram tanto suas importações quanto suas exportações. A queda nas exportações foi menor que nas importações, e, a metalurgia contribuiu muito para isso. A divisão de veículos automotores foi aquela que obteve as maiores recessões no seu comércio, sendo de 49,3\% para as importações e 29,1\% para as exportações. Assim, cabe ressaltar, no que diz respeito à indústria metal mecânica, a melhoria da balança comercial brasileira está mais relacionada a uma queda da demanda interna que de fato a um aumento da competitividade da indústria local que teria melhorado o posicionamento brasileiro no mercado internacional. Para enfatizar isso, basta observar a drástica queda da participação dos investimentos na economia como se encontra descrito por alguns economistas como Bastos e Jorge (2017).

\section{Participação das exportações das regiões selecionadas na metal mecânica brasileira}

As microrregiões que foram selecionadas para a análise na tese tiveram como base o número de empregados nos setores a partir do método descrito acima. Notou-se que mais de $85 \%$ do emprego da metal mecânica em cada um dos anos estudados estava nas 71 regiões selecionadas. Já para o conjunto das exportações, notou-se que a proporção nessas regiões é menor. Isso pode estar relacionado a dois fatos. O primeiro deles diz a uma incompatibilidade das classificações já que a relação entre CNAE e a NCM foi realizada com base na tabela fornecida pela CONCLA-IBGE e pode ter assumido alguns produtos como sendo da metal mecânica de forma equivocada. Contudo, foi preferido não atuar sobre a classificação já fornecida pelo IBGE. O segundo fato diz respeito de regiões que apesar de terem um nível alto de exportações em determinado produto do complexo, isso não reflete em um impacto similar no que diz respeito ao emprego.

A Tabela 1 apresenta o percentual das exportações brasileiras das microrregiões selecionadas para os 4 anos:

Tabela 1: Proporção das regiões selecionadas no total das exportações brasileiras por setor

\begin{tabular}{|l|r|r|r|r|}
\hline Setor & 2006 & 2010 & 2013 & 2016 \\
\hline Metalurgia & 0,608 & 0,531 & 0,721 & 0,626 \\
\hline Produtos de metal & 0,858 & 0,811 & 0,826 & 0,814 \\
\hline Maquinas elétricas & 0,974 & 0,971 & 0,945 & 0,803 \\
\hline Máquinas & 0,958 & 0,953 & 0,881 & 0,696 \\
\hline Automotores & 0,964 & 0,981 & 0,975 & 0,924 \\
\hline Outros transportes & 0,942 & 0,955 & 0,904 & 0,796 \\
\hline Total da Metal ecânica & 0,785 & 0,744 & 0,767 & 0,710 \\
\hline
\end{tabular}

Fonte: Elaboração própria com base nos dados do Comexstat

Em 2006, 78,5\% das exportações estavam nas microrregiões selecionadas e esse valor foi decrescendo até chegar a 71,0\% em 2016. Dentre os setores CNAE, observa-se que, em sua maioria, as regiões selecionadas atingiram mais de $80 \%$ das exportações. O setor de metalurgia não assumiu tal percentual em nenhum dos anos e isso se deve a praticamente com três microrregiões, Belém, São Luiz e $\operatorname{Araxá}^{10}$. Cabe então reforçar que essas microrregiões não atingiram o ponto de corte de empregos formais

\footnotetext{
${ }^{10}$ A microrregião de Belém tem uma forte produção de alumínio da empresa Hydro Alunorte na cidade de Barcarena. A produção tem impacto na economia dessa cidade no que diz a salários e postos de trabalho, entretanto, isso é diluído quando se observa a microrregião de Belém como um todo. Ainda, digno de nota, no ano de 2018 houve um grande vazamento de produtos tóxicos contaminando a infraestrutura hídrica devido à negligência no manejo dos resíduos das companhias locais. Isso leva a quesrionamentos dos reais benefícios líquidos em manter essa produção para a população local e para o
} 
para serem incorporada na análise. Ainda cabe citar a queda no percentual das exportações dos outros materiais de transporte dentre as microrregiões selecionadas para o ano de 2016. Isso ocorreu pelo aumento da exportação desses produtos na Microrregião Serrana do Rio de Janeiro que, sozinha respondeu por $19,8 \%$ de toda a venda internacional da CNAE, ${ }^{11}$ somado às quedas nas exportações de embarcações das localidades selecionadas.

Feita as observações acima, o trabalho seguirá com a análise das 71 microrregiões selecionadas. Em 2006 esse grupo de regiões exportava 24,6 bilhões de dólares em produtos metal mecânicos. Tal valor teve um pequeno aumento para o ano de 2010 sendo de 25,0 bilhões, foi para 34,5 bilhões em 2013 e recuou significativamente para o último ano da análise atingindo 26,4 bilhões em 2016. Quase todas as regiões tiveram pelo menos alguma participação no comércio exterior desses períodos. As únicas exceções ficaram para a microrregião de Itaguara no ano de 2010 e a microrregião da Mata Setentrional Pernambucana em 2013 que não exportaram mercadorias metal mecânicas. A exportação por região também se apresentaram muito importante. Em 2006 e 2010 o número de microrregiões que obteve pelo menos um milhão de dólares no valor de suas vendas externas era de 66, subindo para 69 em 2013 e recuando um pouco para $68 \mathrm{em} 2016^{12}$.

O quadro 1 apresenta o número de microrregiões e quais localidades foram necessárias para atingir pelo menos $50 \%$ das vendas externas:

\section{Quadro 2: Microrregiões que somam juntas pelo menos $50 \%$ do total das exportações selecionadas}

\begin{tabular}{|c|c|}
\hline $2006(52,84 \%)$ & $\begin{array}{l}6 \text { microrregiões: São José dos Campos }(17,14 \%) \text {, São Paulo }(14,96 \%) \text {, Vitória } \\
(6,51 \%) \text {, Curitiba }(5,82 \%) \text {, Salvador }(4,22 \%) \text {, Ipatinga }(4,19 \%)\end{array}$ \\
\hline $2010(53,15 \%)$ & $\begin{array}{l}6 \text { microrregiões: São José dos Campos }(19,71 \%) \text {, São Paulo }(10,79 \%) \text {, Vitória } \\
(7,96 \%) \text {, Campinas }(5,06 \%) \text {, Joinville }(4,98 \%) \text {, Curitiba }(4,65 \%)\end{array}$ \\
\hline $2013(51,58 \%)$ & $\begin{array}{l}5 \text { microrregiões: São José dos Campos }(14,63 \%) \text {, Litoral Lagunar }(14,11 \%) \text {, } \\
\text { Rio de Janeiro }(9,21 \%) \text {, São Paulo }(8,31 \%) \text { e Belo Horizonte }(5,32 \%) \text {. }\end{array}$ \\
\hline $2016(55,40 \%)$ & $\begin{array}{l}5 \text { microrregiões: São José dos Campos }(18,30 \%) \text {, Rio de Janeiro }(15,80 \%) \text {, } \\
\text { Vitória }(8,00 \%) \text {, São Paulo }(7,50 \%) \text {, Baía de Ilha Grande }(5,80 \%)\end{array}$ \\
\hline
\end{tabular}

Fonte: Elaboração própria com base nos dados do Comexstat

O quadro 1 se mostrou bem estável, o que se vê pela presença de boa parte das microrregiões em todos os três períodos bem como pelo número de microrregiões. Tal grupo é um tanto heterogêneo com localidades exportadoras de produtos de alta tecnologia, como é o caso de São José dos Campos, regiões diversificadas como o Rio de Janeiro e ainda localidades marcadas por atividades de metalurgia de baixa intensidade tecnológica como é o caso de Vitória. Essa última é marcada pelo beneficiamento de produtos de metal.

Os indicadores de concentração das exportações não mudaram muito ao longo dos períodos, entretanto, algumas observações podem ser feitas nessa questão. $\mathrm{O}$ índice $\mathrm{HH}$ do valor bruto das pautas regionais de exportações, por exemplo, permaneceu em 0,074 em 2006 e 2010, decrescendo para 0,070 em 2013 e aumentando para 0,082 em 2016. Isso indica que houve uma leve desconcentração entre o 2010 e 2013, que foi mais que revertida para o ano de 2016, o mais concentrado de toda a análise. Os índices de concentração das maiores regiões $(\mathrm{C} 1, \mathrm{C} 4$ e C10) também variaram pouco. Em 2006 o C1, que representa São José para todos os anos, tinha 17,1\% em 2006, 19,7\% em 2010, 14,6\% em 2013 e 18,3\% em 2016. Já o C4 obteve 44,4\% em 2006, 43,5\% em 2010, 46,3\% em 2013 e 49,5\% em 2016. O C10 era de 68,5\% em 2006, 68,8\% em 2010, 69,4\% em 2013 e 71,6\% em 2016.

Embora os índices de concentração não tenham modificado com muita força, a sua composição teve comportamentos dignos de nota. Entre 2010 e 2013 é notório o crescimento do papel das exportações de três microrregiões marcadas pela atividade naval. Em 2010, a microrregião do Litoral Lagunar era a

desenvolvimento da região. A região de São Luis está representada por ser um entreposto de beneficiamento do minério de Carajás e em Araxá pela produção em torno do nióbio de produtos metalúrgico básicos.

11 A presença da região serrana no ano de 2016 está ligada à produção de partes de aeronaves realizado pela empresa GECelma em Petrópolis.

${ }^{12}$ As únicas microrregiões que não atingiram um milhão de dólares em pelo menos um dos quatro períodos analisados foram Nova Friburgo e a Mata Setentrional Pernambucana 
$69^{a}$ região das 71 em exportações e vendia pouco mais de 0,6 milhões de dólares. Já em 2013 a mesma localidade alcançou 4,86 bilhões de dólares e atingiu 14,11\% de total das exportações de todas as regiões selecionadas. Esse valor ficou abaixo apenas de São José dos Campos. Movimento similar foi observado também na região fluminense de Baía de Ilha grande. Essa exportava apenas 112 milhões de dólares em 2010 e elevou seu nível de vendas para o exterior para 1,4 bilhões em 2013 sendo a sexta maior região exportadora nesse último ano. Já a microrregião de Suape tinha apenas 27,9 milhões em exportações em 2010 e elevou-se para 1,17 bilhões e alcançando a nona posição em 2013. Essa competitividade internacional revelada pelo aumento do movimento do comércio exterior nessas regiões não se manteve. Das três regiões acima mencionadas, apenas a Baía de Ilha Grande aumentou suas exportações para o ano de 2016. Por fim, cabe dizer que enquanto as 71 regiões somadas aumentaram em 9 bilhões de dólares suas exportações em 2013 com relação a 2010, apenas as três regiões acima mencionadas aumentaram 7,3 bilhões. Por outro lado, enquanto o Brasil diminuiu suas exportações em U\$7,9 bilhões no ano de 2016, as três mesmas localidades reduziram em U\$5,9 bilhões ${ }^{13}$. Esses dados mostraram a importância estratégica da indústria naval para a economia brasileira para a geração de superávits na balança comercial, notando que o desincentivo governamental ao setor gerou impactos locais significativos e o setor se encontra praticamente desarticulado nas duas localidades acima mencionadas.

Comparando o início e o fim do período estudado, 34 microrregiões aumentaram suas exportações e outras 37 diminuíram. Dentre aquelas que aumentaram Itaguara é a que mais se destaca. A localidade praticamente não exportava em 2006 e passou a ter 275 milhões de dólares em 2016, sendo que já havia chegado a 431 milhões em 2013. Esses números se devem às vendas da fábrica da Valorec/Sumitomo de tubos de aço sem costura determinada pela classe 7304 do Sistema Harmônico de quatro dígitos. As outras duas microrregiões que mais cresceram nessa medida foram o Litoral Lagunar e a Baía de Ilha Grande que já foram explanadas no parágrafo acima. Já observando as regiões que mais deixaram de exportar em porcentual, observa-se que muitas delas tinham quantidades brutas muito pequenas de vendas ao exterior e então a variação dessa medida não tem muito valor. Todavia, algumas regiões sofreram quedas significativas. Dentre essas regiões, destaca-se Ipatinga. Essa tradicional localidade industrial de Minas Gerais era a sexta região que mais exportava em 2006 alcançando 1,03 bilhões de dólares. Em 2016 ela exportou apenas 385 milhões de dólares. Essa queda não pode ser atribuída à crise entre os dois últimos períodos 2013-2016, já que foi observada uma tendência decrescente entre todos os períodos da análise. Duas capitais também passaram por quedas interessantes no total de suas exportações. Em 2016, São Paulo exportava apenas 54\% do que fazia em 2006 e representava 14,96\% do total das exportações em 2006, passando a apenas 7,5\% em 2016. Por fim, Belo Horizonte que tinha 4,0\% das vendas totais em 2006 e passou para 2,4\%. Essa última microrregião teve os efeitos derivados do período de crise econômica brasileira com mais evidência já que suas exportações haviam duplicado entre 2006 e 2013 caindo vertiginosamente no último período. A maior parte da queda dessa última deveu-se a três produtos em ordem de impacto, metalurgia de ouro, motores de ignição a faíscas e tubos e tubagens de aço sem costura.

\section{O destino das exportações das microrregiões}

O quadro 2 abaixo demonstra os países que, juntos, responderam como destino de pelo menos $50 \%$ das vendas brasileiras de produtos da metal mecânica. Ele 2 demonstrou que no período analisado também não ocorreram grandes mudanças nos destinos de exportação das microrregiões de metalmecânica brasileira evidenciando o papel principalmente dos Estados Unidos, Argentina, e Países Baixos nos shares vendidos dos quatro períodos. Os Estados Unidos foi um grande exportador de materiais metalúrgicos e produtos de metal, a Argentina se destacou como destino de máquinas e equipamentos e veículos automotores e os Países Baixos ${ }^{14}$ foi um importante destino para embarcações.

\footnotetext{
${ }^{13}$ Mesmo somando o pequeno aumento na microrregião de Baia de Ilha Grande.

${ }^{14}$ Fica localizada em Roterdã a Repetro, subsidiária da Petrobrás responsável pela comercialização internacional da estatal brasileira. Isso ajuda a entender porque o país se constitui de um destino importante para embarcações brasileiras.
} 


\section{Quadro 3: Destinos que somam juntos pelo menos 50\% do total das exportações selecionadas}

\begin{tabular}{|l|l|}
\hline $2006(50,02 \%)$ & $\begin{array}{l}5 \text { países: Estados Unidos (27,66\%), Argentina (9,39\%), Alemanha (4,62\%), } \\
\text { México (4,46\%) e Canadá (3,89) }\end{array}$ \\
\hline $2010(51,1 \%)$ & $\begin{array}{l}\text { 6 países: Argentina (15,74\%), Estados Unidos (15,22\%), Países Baixos (6,07\%), } \\
\text { México (5,08\%), Alemanha(4,97\%) e China (3,93\%) }\end{array}$ \\
\hline $2013(53,18 \%)$ & $\begin{array}{l}\text { 4 países: Estados Unidos (19,19\%), Panamá (12,29\%), Países Baixos (11,31\%) e } \\
\text { Argentina (10,39\%) }\end{array}$ \\
\hline $\begin{array}{l}\text { 4 países: Estados Unidos (25,08\%), Países Baixos (12,45\%), Argentina (8,55\%) e } \\
\text { Cingapura (6,05\%) }\end{array}$ \\
\hline
\end{tabular}

Fonte: Elaboração própria com base nos dados do Comexstat

Passando para o cálculo das medidas sugeridas na metodologia, nota-se que o preenchimento da matriz não se modificou significativamente e apresentou até uma pequena queda. Em 2006, 23,59\% das combinações países de destino - microrregiões de origem obtiveram pelo menos um dólar de comércio entre eles. Esse valor caiu para 22,22\% em 2010, 21,99\% em 2013 e elevou-se um pouco para 22,97\% em 2016. Isso permite que seja inferido que as microrregiões selecionadas, em média, tiveram dificuldades de conseguir novos mercados para seus produtos. Assim, pode-se dizer que a dificuldade de diversificação de mercados aumenta a fragilidade dos agentes locais a problemas em países específicos que podem fazer com que encerrem a sua inserção no mercado externo.

Também não houve mudanças muito significativas nos mercados de cada região. Por exemplo, a Microrregião de São Paulo foi aquela que tinha um maior número de mercados em 2006 em que atingia $64,96 \%$ dos 234 países. Ela se manteve com o maior índice de participação entre as linhas durante todos os períodos, mesmo que tenha perdido um pouco do valor do seu cociente. Em 2006, apenas seis localidades tinha como destino de suas exportações $50 \%$ ou mais países da tabela e esse número reduziu para cinco em 2010, sendo assim mantido pelos anos seguintes. A estabilidade nessa medida é tão significativa que o grupo das 9 primeiras microrregiões se mantiveram ao longo dos quatro períodos estudados, mesmo que tenha ocorrido mudanças dentre elas. O maior crescimento em pontos percentuais de participação entre 2006-2016 ficou a cargo de Recife e Ijuí. A primeira dessas regiões atingia 16,67\% dos destinos e passou para $26,07 \%$, já a segunda mantinha vendas internacionais para $6,84 \%$ em 2006 dos países e passou para $26,07 \%$.

Em média o índice de $\mathrm{HH}$ para os países encontrados estava relativamente alto, sendo que ficou entre 0,23 e 0,24 para os quatro períodos. Contudo, algumas regiões ainda apresentaram HHs pequenos. Em 2006, Fortaleza tinha um HH de 0,057, seguido pela microrregião de Marília $(0,068)$ e Conselheiro Lafaiete (0,069). Em 2010, os menores eram São José dos Campos $(0,056)$, Caxias do Sul $(0,075)$ e Limeira (0,082). Já em 2013 essas três regiões com destinos mais desconcentrados eram São João da Boa Vista $(0,056)$, Blumenau $(0,073)$ e Araraquara $(0,079)$. Por fim, em 2016, essas localidades eram São João da Boa Vista $(0,055)$, Blumenau $(0,067)$ e Caxias do Sul $(0,075)$.

Das microrregiões que obtiveram os maiores índices de concentração, excetuando aquelas regiões com exportações menores que um milhão, em 2006 foram Jaú $(0,751)$, Cascavel $(0,512)$ e Bocaiúva $(0,508)$. Em 2010, Bocaiúva $(0,992)$ era a região mais concentrada seguida por Baía de Ilha Grande $(0,830)$ e Goiânia $(0,682)$. Em 2013, esse grupo tinha como localidades Suape $(0,965)$, Baía de Ilha Grande $(0,950)$ e Botucatu $(0,866)$. Em 2016, Baía de Ilha grande $(0,998)$ era a mais concentrada seguida por Litoral Lagunar $(0,983)$ e Botucatu $(0,899)$. Assim, fica evidente como as microrregiões que mais cresceram entre 2010 e 2013 também se concentraram significativamente no que diz sobre os destinos de seus produtos. Essa concentração se dá pela venda de produtos da indústria naval para os Países Baixos.

A correlação entre os anos deve ser interpretada de forma que quanto mais próxima de 1 mais parecidas são as superfícies das matrizes (RIBEIRO et.al, 2010). Assim, para o cálculo da matriz de origem-destino, foi possível observar alguma relação entre as superfícies, ou seja, as matrizes obedecem alguma relação entre elas e não é possível dizer que os destinos se comportam de forma aleatória. A tabela 2 abaixo demonstra a correlação entre os quatro períodos 


\section{Tabela 2: Matriz de correlação das matrizes de origem-destino das exportações de produtos metal} mecânicos nas regiões selecionadas

\begin{tabular}{|c|c|c|c|c|}
\hline & 2006 & 2010 & 2013 & 2016 \\
\hline 2006 & 1 & & & \\
\hline 2010 & 0,672 & 1 & & \\
\hline 2013 & 0,413 & 0,419 & 1 & \\
\hline 2016 & 0,623 & 0,552 & 0,478 & 1 \\
\hline \multicolumn{5}{|c|}{ Fonte: Elaboração própria com base nos dados do Comexstat }
\end{tabular}

Assim, notou-se que a matriz de 2013 teria sido aquela mais diferente entre as quatro e isso pode está relacionado com o fato de nesse ano o setor naval ter tido um grande peso nessas exportações. Em 2016, as exportações recuam e se reforça nos mercados tradicionais para os anos de 2006 e 2010 . Esse indicador também contribuiu para a hipótese de que a mudança na pauta brasileira tenha sido esporádica e perdido qualquer força já em 2016.

\section{A diversificação das exportações das microrregiões}

Outra forma de avaliar o desempenho das regiões é como se dispõe os produtos em uma matriz de relação com as localidades. A correspondência entre as CNAEs previamente selecionadas e os produtos que as representam gerou 299 diferentes mercadorias. Dessas, 285 foram exportadas por uma das 71 regiões em pelo menos um dos períodos analisados e Dos 285 produtos, apenas 11 deles não eram exportados em 2006, 9 não eram em 2010, 6 em 2013 e 7 em 2016.

Uma forma interessante para se mostrar a distribuição dos produtos é obsevar a cesta que compõe $50 \%$ da pauta de exportações das 71 regiões selecionadas. Nota-se que o número de produtos necessário para atingir esse corte reduziu como pode ser visto no Quadro 3. Assim, em 2013, ano com o maior volume de venda para o exterior, apenas 7 produtos eram responsáveis por mais da metade de toda a pauta de exportação. Nota-se o peso forte da fabricação de aeronaves (8802) que só perdeu o primeiro posto em 2013 para a fabricação de embarcações (8905). Essas duas classes foram as únicas a apresentarem um share de pelo menos $10 \%$, sendo que a primeira obteve tal valor em todos os anos e a segunda apenas em 2013 e 2016.

$\mathrm{O}$ índice de preenchimento geral das matrizes, assim como o foi demonstrado para a matriz de origem-destino, não obtiveram valores muito altos. Em 2006, esse índice foi de 26,20\%, elevando-se para 27,07\% em 2010, 27,69\% em 2013 e 30,50\% em 2016. Em 2006, havia doze microrregiões que exportavam pelo menos a metade dos produtos selecionados. Número que se manteve em 2010 e acresceu para treze nos períodos sequentes de 2013 e 2016. Para o preenchimento ao nível das linhas, que representa a capacidade de cada microrregião de exportar pelo menos uma unidade monetária de cada produto, notou-se que houve uma correlação muito forte entre os anos. Isso indica certa dificuldade de uma localidade em diversificar sua cesta de exportações. Outro fato que demonstra isso que as 10 regiões mais diversificadas variam muito pouco, ou seja, dos mais bens posicionados em 2006, apenas um não estava em 2010 e 2013 e dois em 2016. Apresentando o indicador em si, nota-se que em 2006, as três microrregiões que mantinham exportações em um maior número de setores eram, em sequência, São Paulo, Rio de Janeiro e Campinas, o que se mantém para 2010 e 2016. Apenas em 2013 que Campinas cedeu sua posição para Belo Horizonte.

Dentre as microrregiões que mais concentraram suas produções em produtos específicos e que assumiu um volume significativo de suas exportações ${ }^{15}$ para 2006 destacam-se uma localidade com $\mathrm{HH}$ máximo, Rio Preto da Eva, além de outras duas regiões com índice maior que 0,9 , como Catalão $(0,998)$ e Santa Rosa (0,924). Em 2010, Rio Preto da Eva e Catalão também ocuparam primeira e segunda posição respectivamente sendo que foram seguidos por Bocaiúva $(0,856)$. Já em 2013, as três microrregiões mais concentradas tinham HH igual a um e eram, Itaguara, Baía de Ílha grande e Rio preto da Eva nessa ordem. As duas primeiras se mantiveram para 2016 além de ter sido acrescentado o Litoral Lagunar $(0,998)$ no terceiro posto.

\footnotetext{
${ }^{15}$ Que representam pelo menos um milhão de dólares de vendas.
} 


\section{Quadro 3: Produtos que somam juntos pelo menos 50\% do total das exportações selecionadas}

\begin{tabular}{|c|c|}
\hline $\begin{array}{l}2006 \\
(50,12 \%)\end{array}$ & $\begin{array}{l}13 \text { produtos: } 8802 \text { - Outras aeronaves (como helicópteros e aviões) espaçonaves (incluindo satélites) e } \\
\text { suborbitais e veículos lançadores }(12,93 \%), 7207 \text { - Produtos semiacabados de ferro e aços não ligados }(7,53 \%) \text {, } \\
8409 \text { - Acessórios para o uso separadamente o juntamente com motores de posição das classes } 8407 \text { e } 8408 \\
(6,00 \%), 7208 \text { - Produtos laminados prontos de ferro ou ferros não ligados, com largura de } 100 \text { mm ou mais, } \\
\text { laminado a alta temperatura, não revestidos }(3,81 \%), 8408 \text { - Motores de pistão, de ignição por compressão } \\
\text { (motores diesel ou semidiesel) }(3,24 \%), 8407 \text { - Motores de pistão, alternativo ou rotativo, de ignição por faísca } \\
\text { (motores de explosão) }(2,66 \%), 7201 \text { - Ferro gusa e outros blocos de formas primárias }(2,15 \%), 8413 \text { - Bombas } \\
\text { para líquidos, mesmo equipadas com um dispositivo de medição; elevadores de líquidos; parte do mesmo } \\
(1,75 \%), 8414 \text { - Bombas de ar ou de vácuo, compressores de ar ou outros gases e ventiladores; exaustores de } \\
\text { ventilação ou reciclagem, com ventilador incorporado, mesmo com filtros; suas partes (3,57\%), } 8418 \text { - } \\
\text { Refrigeradores, congeladores e outros equipamentos de refrigeração ou congelação, elétricos ou outros; bombas } \\
\text { de calor, exceto as máquinas de ar condicionado da posição } 8415 \text {; suas partes (1,68\%), } 8483 \text { - Eixos de } \\
\text { transmissão (incluindo árvores de cames e virabrequins) e manivelas; caixas de mancais, mancais de mancais e } \\
\text { mancais de eixo liso; engrenagens e engrenagens; Parafusos de esferas ou de rolos; caixas de transmissão e } \\
\text { outros dispositivos de mudança de velocidade, incluindo conversores de binário; volantes e pul (1,64\%), } 7219 \text { - } \\
\text { Produtos laminados de aço inoxidável, com comprimento de } 600 \text { mm ou mais (1,63\%), } 7403 \text { - Cobre refinado e } \\
\text { ligas de cobre em forma bruta ( } 1,54 \%) \text {, }\end{array}$ \\
\hline $\begin{array}{l}2010 \\
(51,61 \%)\end{array}$ & $\begin{array}{l}12 \text { produtos: } 8802 \text { - Outras aeronaves (como helicópteros e aviões) espaçonaves (incluindo satélites) e } \\
\text { suborbitais e veículos lançadores }(15,45 \%), 7207 \text { - Produtos semiacabados de ferro e aços não ligados }(9,01 \%) \text {, } \\
8409 \text { - Acessórios para o uso separadamente o juntamente com motores de posição das classes } 8407 \text { e } 8408 \\
(5,81 \%), 8414 \text { - Bombas de ar ou de vácuo, compressores de ar ou outros gases e ventiladores; exaustores de } \\
\text { ventilação ou reciclagem, com ventilador incorporado, mesmo com filtros; suas partes }(3,63 \%) \text {, } 8407 \text { - Motores } \\
\text { de pistão, alternativo ou rotativo, de ignição por faísca (motores de explosão) }(2,78 \%), 7108 \text { - Ouro (incluindo o } \\
\text { ouro platinado), em formas brutas ou semimanufaturadas, ou em pó }(2,83 \%), 8307 \text { - Tubos flexíveis de metal } \\
\text { base, com ou sem acessórios }(2,51 \%), 8481 \text { - Torneiras, válvulas (incluídas as redutoras de pressão e as } \\
\text { termostáticas) e dispositivos semelhantes, para canalizações, caldeiras, reservatórios, cubas e outros recipientes e } \\
\text { suas partes (2,25\%), } 8483 \text { - Eixos de transmissão (incluindo árvores de cames e virabrequins) e manivelas; } \\
\text { caixas de mancais, mancais de mancais e mancais de eixo liso; engrenagens e engrenagens; Parafusos de esferas } \\
\text { ou de rolos; caixas de transmissão e outros dispositivos de mudança de velocidade, incluindo conversores de } \\
\text { binário; volantes e pul (2,09\%), } 8413 \text { - Bombas para líquidos, mesmo equipadas com um dispositivo de } \\
\text { medição; elevadores de líquidos; parte do mesmo (2,02\%), } 7208 \text { - Produtos laminados prontos de ferro ou ferros } \\
\text { não ligados, com largura de } 100 \text { mm ou mais, laminado a alta temperatura, não revestidos }(1,84 \%), 8408- \\
\text { Motores de pistão, de ignição por compressão (motores diesel ou semidiesel) (1,70\%), }\end{array}$ \\
\hline $\begin{array}{l}2013 \\
(50,97 \%)\end{array}$ & $\begin{array}{l}7 \text { produtos: } 8905 \text { - Embarcações leves, dragas, guindastes flutuantes e outras embarcações cuja navegabilidade é } \\
\text { subsidiária à sua função principal; docas flutuantes; plataformas de perfuração ou produção flutuantes ou } \\
\text { submersíveis }(21,34 \%), 8802 \text { - Outras aeronaves (como helicópteros e aviões) espaçonaves (incluindo satélites) e } \\
\text { suborbitais e veículos lançadores }(11,01 \%), 7207 \text { - Produtos semiacabados de ferro e aços não ligados }(6,00 \%) \text {, } \\
8409 \text { - Acessórios para o uso separadamente o juntamente com motores de posição das classes } 8407 \text { e } 8408 \\
(4,88 \%), 8307 \text { - Tubos flexíveis de metal base, com ou sem acessórios }(2,92 \%), 7108 \text { - Ouro (incluindo o ouro } \\
\text { platinado), em formas brutas ou semimanufaturadas, ou em pó }(2,92 \%), 8414 \text { - Bombas de ar ou de vácuo, } \\
\text { compressores de ar ou outros gases e ventiladores; exaustores de ventilação ou reciclagem, com ventilador } \\
\text { incorporado, mesmo com filtros; suas partes ( } 2,47 \%) \text {, } 8481 \text { - Torneiras, válvulas (incluídas as redutoras de } \\
\text { pressão e as termostáticas) e dispositivos semelhantes, para canalizações, caldeiras, reservatórios, cubas e outros } \\
\text { recipientes e suas partes }(2,30 \%) \text {. }\end{array}$ \\
\hline $\begin{array}{l}2016 \\
(50,05 \%)\end{array}$ & $\begin{array}{l}8 \text { produtos: } 8802 \text { - Outras aeronaves (como helicópteros e aviões) espaçonaves (incluindo satélites) e suborbitais } \\
\text { e veículos lançadores }(15,71 \%), 8905 \text { - Embarcações leves, dragas, guindastes flutuantes e outras embarcações } \\
\text { cuja navegabilidade é subsidiária à sua função principal; docas flutuantes; plataformas de perfuração ou produção } \\
\text { flutuantes ou submersíveis }(13,02 \%), 7207 \text { - Produtos semiacabados de ferro e aços não ligados }(6,08 \%), 7108- \\
\text { Ouro (incluindo o ouro platinado), em formas brutas ou semimanufaturadas, ou em pó }(5,01 \%), 8409- \\
\text { Acessórios para o uso separadamente o juntamente com motores de posição das classes } 8407 \text { e } 8408(4,16 \%) \text {, } \\
8307 \text { - Tubos flexíveis de metal base, com ou sem acessórios }(3,24 \%), 8481 \text { - Torneiras, válvulas (incluídas as } \\
\text { redutoras de pressão e as termostáticas) e dispositivos semelhantes, para canalizações, caldeiras, reservatórios, } \\
\text { cubas e outros recipientes e suas partes }(2,82 \%), 7224 \text { - Outras ligas de aço, em lingotes ou outras formas } \\
\text { primárias; produtos semimanufaturados de outras ligas de aço }(2,75 \%) \text {, }\end{array}$ \\
\hline
\end{tabular}

Fonte: Elaboração própria com base nos dados do Comexstat

A matriz de correlação para os quatro períodos apresentada abaixo demonstrou que as estruturas das pautas de exportação pouco variaram entre 2006 e 2010, mas tiveram uma variação significativa entre 2006 e 2013. É interessante observar que esse resultado coincide com a mudança de destino como foi 
descrito na matriz acima e no período seguinte em que o correu a redução da participação da indústria naval concomitantemente com o volume total das exportações, a matriz ficou mais similar. Esse último fato aparece na correlação entre 2006 e 2016. Ainda corroborando com o que foi dito acima nota-se que a correlação entre 2010 e 2016 foi significativamente maior que a correlação entre 2013 e 2016 além de a correlação entre 2013 e 2016 responder pelo menor valor na comparação entre dois períodos sequentes.

\begin{tabular}{|c|c|c|c|c|}
\hline & 2006 & 2010 & 2013 & 2016 \\
\hline 2006 & 1 & & & \\
\hline 2010 & 0,944 & 1 & & \\
\hline 2013 & 0,571 & 0,604 & 1 & \\
\hline 2016 & 0,793 & 0,833 & 0,670 & 1 \\
\hline \multicolumn{7}{|c|}{ Fonte: Elaboração própria com base nos dados do Comexstat }
\end{tabular}

$\mathrm{O}$ índice $\mathrm{HH}$ dos produtos para as microrregiões também apresentou índices bem altos. Em 2006, o índice médio para as localidades era de 0,350, esse decresceu para 0,325 em 2010, elevou-se para 0,362 em 2013 e finalizou o período com 0,345. Por outro lado, pode-se notar que haviam microrregiões bem mais desconcentradas nessa medida. Em 2006, oito localidades obtiveram menos de 0,1 nesse índice e dessas, as três menores eram São Paulo $(0,047)$, Campinas $(0,065)$ e Porto Alegre $(0,067)$. São Paulo $(0,040)$ mantém sua posição com um índice ainda menor para 2010, e passou a ser seguido por Sorocaba $(0,066)$ e Osasco $(0,074)$. As duas últimas localidades se mantiveram em 2010 e a última deu lugar a Guarulhos $(0,062)$. Já em 2016, ocorre uma mudança em todos os três primeiros postos, passando a ter Sorocaba $(0,050)$, Caxias do Sul $(0,052)$ e Campinas $(0,053)$ nas três primeiras posições.

A Figura 3 apresenta os mapas de calor (heatmaps) em que são disponibilizados os valores das exportações em logaritmo natural para todas as mercadorias. Os produtos estão em ordem de sua intensidade tecnológicas de acordo com o sugerido por Lall (2000) e pela numeração no sistema SH4. Assim, os produtos menos sofisticados se encontram a direita e os mais sofisticados à esquerda. Já as microrregiões estão distribuídas de acordo com sua localização dentre as regiões naturais do Brasil e assim a mais embaixo é Manaus (região Norte) e a mais acima é Catalão (Centro-Oeste). Após o Norte se estão as regiões do Nordeste, seguidas pelas regiões do Sudeste e depois Sul. A análise seguirá com uma descrição das exportações de cada localidade. Assim, as localidades puderam ser divididas em três grupos para cada ano como: (i) microrregiões da pauta especializada que consiste em localidades que um produto da classe SH4 responde por 50\% ou mais das exportações; (ii) exportações diversificadas com ênfase em um produto específico, quando algum produto atinge pelo menos um terço da pauta; e (iii) exportações diversificadas quando a localidade não atinge nenhuma das condições acima.

Nas microrregiões da região Norte notou-se que Manaus detém um coeficiente de exportações em outros materiais de transportes, mais especificamente na venda de motocicletas. Para 2006 67,75\% do total foi nesse produto e em 2013 50,65\%. Nos outros dois anos a fabricação de motocicletas continuou com os maiores valores de exportações, mas não atingiram os 50\%. Já a microrregião de Rio Preto da Eva teve as vendas externas em produtos de metal em tântalo como as mais relevantes se destacando com 100\% do mercado externo de metal mecânica dessa localidade para 3 dos quatro períodos analisados.

Das microrregiões do Nordeste Fortaleza apresenta uma pauta bem diversificada e só teve uma ênfase em algum produto para o ano de 2013 na indústria naval. A microrregião da Mata Setentrional Pernambucana, mesmo que tenha apresentado um aumento significativo na indústria automotiva em 2016 visto pelo número de empregos, ainda não tem valores de exportação significativos nesse produto. Recife também apresenta uma pauta diversificada, entretanto, em 2016 houve uma especialização muito forte em metalurgia de laminados de ferro sendo que esse respondeu por 56,31\% das exportações. Já na microrregião de Suape, pôde ser observada uma mudança significativa da pauta seguida de um recuo para o modelo antigo. Em 2006 e 2010, 70\% das exportações ou mais eram em produtos de metais que constituíam em tampas e acessórios de embalagens. Em 2013, microrregião teve 98,23\% das suas vendas para o exterior em produtos da indústria naval e em 2016 retornou-se para a mesma estrutura de 2010. Por último, a microrregião de Salvador apresentou uma pauta diversificada com ênfase em metalurgia de cobre nos anos de 2006 e 2010 e se especializou na metalurgia de cobre em 2013 e 2016. 
Figura 3-a - Diversificação produtiva 2006

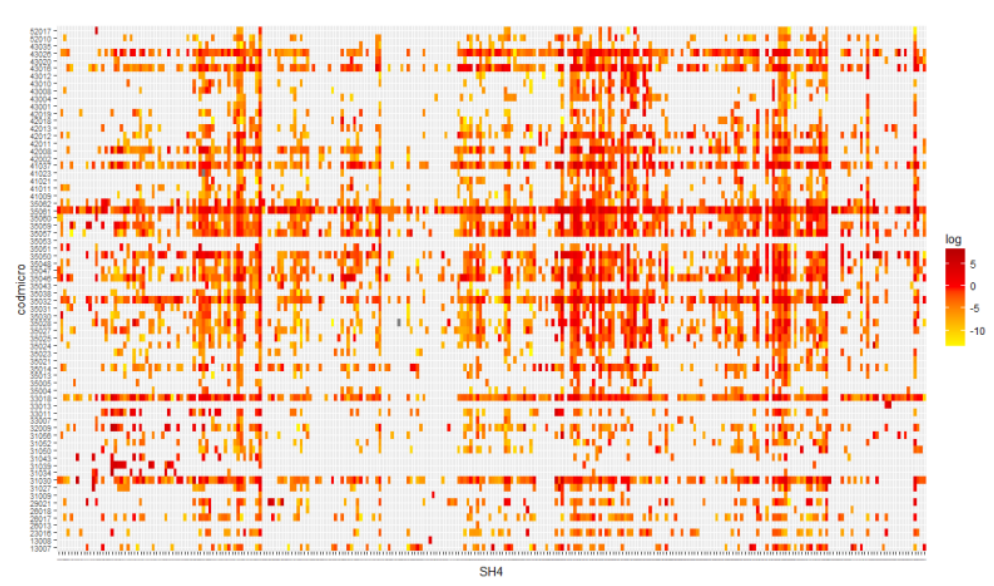

Figura 3-b - Diversificação produtiva 2010

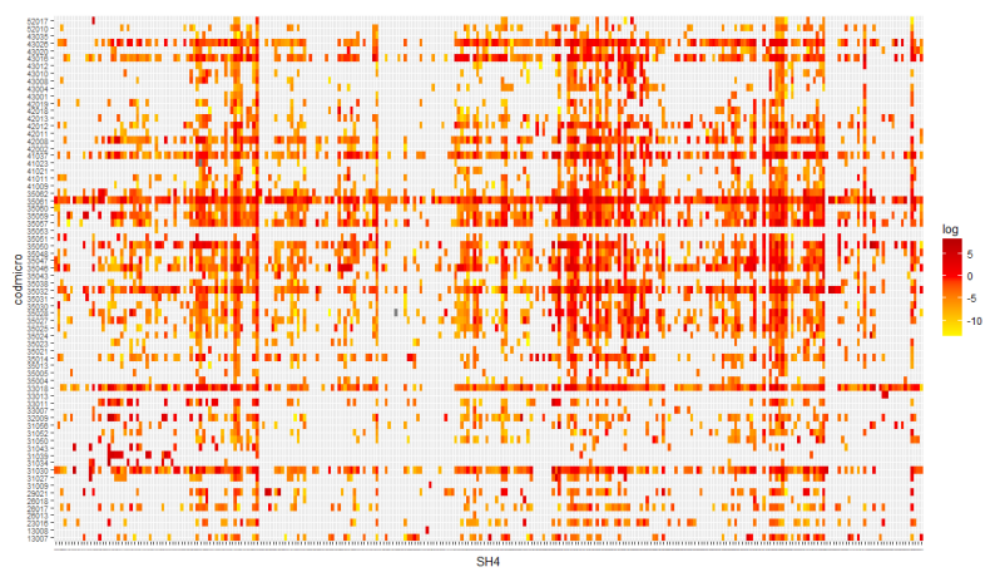

\section{Figura 3-c - Diversificação produtiva 2013}

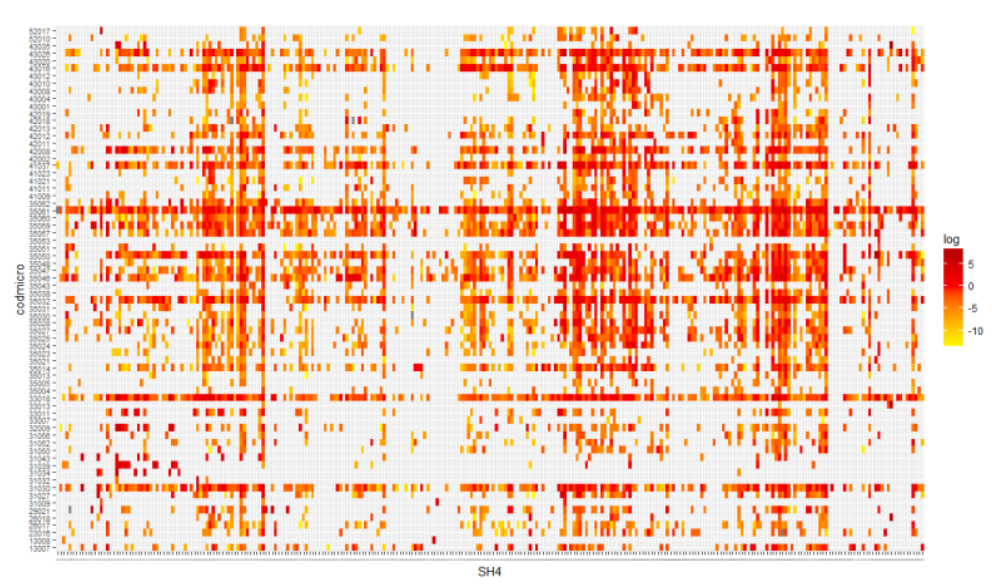

Figura 3-d - Diversificação produtiva 2016

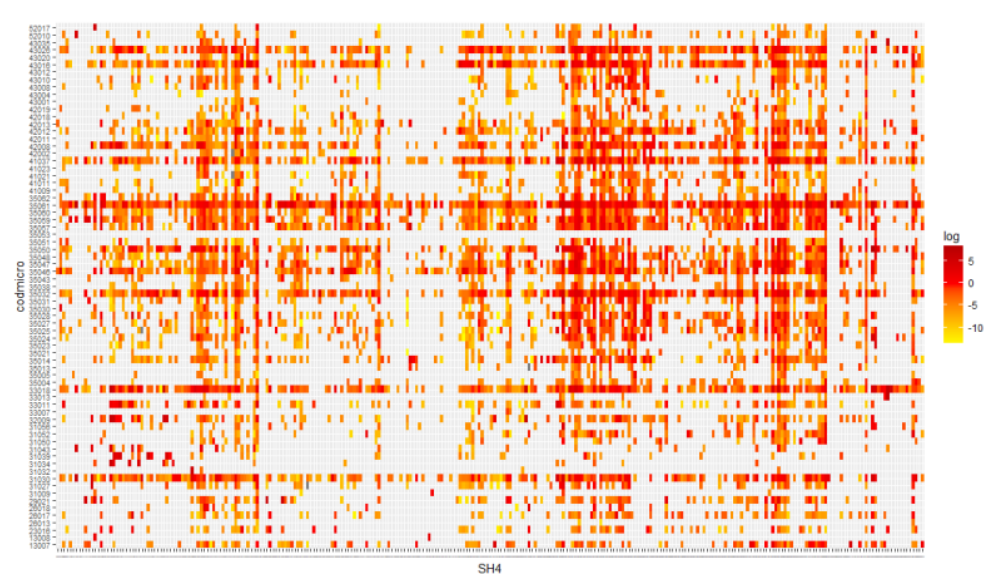

Fonte: Elaboração própria com base nos dados do Comexstat 
O estado de Minas Gerais tem uma histórica inclinação à indústria metalúrgica e boa parte de suas regiões selecionadas corroboraram com isso. Contudo, tal metalurgia se apresentou muito diversificada, tendo Bocaiúva, por exemplo, mantendo a partir de 2013, mais de $80 \%$ das suas exportações em metalurgia do cobre. A metalurgia do ferro está muito presente nas vendas do estado, entretanto, pode-se notar que ela cumpre papeis diferentes nas vendas regionais, bem como existe uma cesta diversificada desses produtos. A microrregião de Sete Lagoas teve pelo menos $60 \%$ de suas exportações em ferro gusa, mesmo produto que representou $42 \%$ das exportações de Divinópolis em 2006. Já Ipatinga tinha exportações diversificadas com ênfases na metalurgia de laminados de ferro até 2013, e em 2016 esse produto passou a ocupar mais de $50 \%$ da pauta. Já Conselheiro Lafaiete se manteve como exportadora especializada em metalurgia de produtos de ferro semiacabados. Ainda observando diversificação da metalurgia local, nota-se que Belo Horizonte e Divinópolis, apesar de terem uma pauta diversificada, tiveram a metalurgia do ouro preenchendo boa parte de suas pautas em 2013 e 2016. Fora da indústria metalúrgica, se destaca a microrregião de Itaguara na produção de produtos de metal em 2013 e 2016. As outras três microrregiões do estado tiveram pautas setorialmente diferentes das anteriores. Para Varginha foi observada uma forte participação de materiais da eletromecânica. Já Itajubá e Pouso Alegre têm suas pautas baseadas em insumos para a indústria de transporte sendo que a primeira fornece partes para motores e a segunda fornece assentos.

A microrregião de Vitória está muito influenciada pela produção metalúrgica de Minas Gerais e assim as exportações para 2006 e 2010 estiveram especializadas na metalurgia de produtos de ferro semiacabados. Essa especialização foi diminuindo e a região se apresenta bem mais diversificada em 2016, apesar de tal produto principal ainda compreender 31\% da pauta. Essa atividade está relacionada com a infraestrutura desse local que conta com um porto ligado à exportação de minério de ferro bruto e produtos metalúrgicos das primeiras etapas de produção.

Para as microrregiões do estado do Rio de Janeiro, observou-se que em 90,21\% das exportações de Nova Friburgo provinham da produção de produtos de metal com ênfase em chaves e cadeados. Em 2013, essa especialização passou para ferramentaria para uso específico, mas voltou para chaves s cadeados em 2016. A microrregião do Vale do Paraíba Fluminense tinha uma pauta bastante diversificada para os primeiros períodos. Porém, em 2013 tinha mais de um terço de suas exportações em motores para a indústria de transportes e, em 2016, em metalurgia do ferro. A Baía de Ilha Grande se manteve especializada na exportação de produtos da indústria naval durante os quatro períodos da base. O Rio de Janeiro esteve bastante diversificado em 2006 e 2010, assumindo uma ênfase em metalurgia de ferro em 2013 e em produtos da indústria naval para 2016.

O Estado de São Paulo se destaca por ter uma indústria em máquinas e em transportes. Nessa indústria de máquinas também pode ser notado uma heterogeneidade interna da produção interessante. A microrregião de Catanduva teve sua pauta especializada em máquinas agrícolas. Comportamento similar ocorreu em Jaboticabal, apesar de essa localidade ter atingido $50 \%$ das vendas externas nesse produto apenas em 2013. As microrregiões de Araraquara, em 2013, e São Jose do Rio Preto, em 2016, também estiveram especializadas nesse grupo de produtos. Essa última localidade ainda tinha se apresentado com mais da metade de suas vendas para o exterior em esteiras não mecanizadas para o ano de 2006. A microrregião de Jaú sempre manteve uma pauta altamente concentrada em partes gerais de máquinas e equipamentos. Tal grupo de produtos também foi o mais presente nas exportações de Bragança Paulista, entretanto, eles atingiram pelo menos um terço da pauta apenas em 2006, ou seja, a localidade tende mais a ser classificada como diversificada. Já São Carlos obteve uma pauta especializada em bombas e compressores de ar, Marília em extintores de incêndio, Tatuí em maquinário eletromecânico e Itapecerica da Serra, apesar de uma pauta diversificada, teve ênfase em máquinas hidráulicas.

Ainda no estado de São Paulo, mas se tratando da indústria de materiais de transportes, nota-se a especialização de Moji mirim em motores e ênfase na pauta, mesmo produto em Limeira para 2006, 2010 e 2016 e em Paraibuna/Paraitinga para 2006. Em 2010 e 2013, Jundiaí apresentou mais de um terço de suas vendas para o exterior em transmissão de automóveis. A microrregião de Botucatu era muito diversificada até 2010 e nas observações de 2013 e 2016 apresentou mais de $90 \%$ de suas exportações em insumos e partes para a indústria de aviação. Os produtos da indústria de aviação dominaram a pauta de 
exportação de São José dos Campos em todos os anos, Araraquara para 2006, 2010 e 2016 e em Paraibuna/Paraitinga para 2010, 2013 e 2016.

Outras microrregiões tiveram pautas especializadas em outros produtos como a metalurgia do alumínio em São João da Boa Vista, uma pauta com ênfase em metalurgia do ferro para 2006 e 2016 em Piracicaba e ênfase em tubos de ferro e aço para o ano de 2010 em Guaratinguetá. Ainda seis outras microrregiões não obtiveram um terço da pauta exportadora em um produto, ou seja, estiveram suas exportações diversificadas por todos os períodos. Essas localidades são Campinas, Sorocaba, Osasco, Guarulhos, São Paulo e Mogi das Cruzes.

$\mathrm{O}$ estado do Paraná também tem uma heterogeneidade interessante entre as suas microrregiões. Maringá teve uma pauta diversificada com ênfase produtos de metal em 2006 e 2010 e em esteiras não mecanizadas em 2013. Londrina tinha uma pauta especializada na venda de elevadores e teleféricos em 2006 e 2010. Após esse último período observou-se que as exportações se diversificaram, mas, a localidade praticamente deixa de exportar aqueles produtos que marcaram sua pauta nos períodos anteriores. Ponta Grossa também tem exportações muito diferenciadas, mas houve ênfase em ferramentaria para 2010 e produtos de alumínio em 2013 e 2016. Já Cascavel obteve ênfase em máquinas e equipamentos e para funções específicas. Por fim, Curitiba tinha ênfase na venda de motores em 2006, mas se tornou totalmente diversificada a partir de 2010.

Santa Catarina tem muitas de suas microrregiões selecionadas bastante diversificadas, e, além disso, tem localidades voltadas para a produção metalúrgica e para a produção de máquinas e equipamentos. A microrregião de Tubarão tinha uma pauta especializada em metalurgia de alumínio para 2006 e 2010 e em 2013 e 2016 uma pauta diversificada, porém, com ênfase em esteiras não mecanizadas. Itajaí apresentou pautas bastante diversificadas com exceção para o ano de 2016 em que metalurgia do chumbo representava pelo menos um terço das vendas. Já a microrregião de Rio do Sul detinha ênfase na exportação de produtos de metal, como porcas e parafusos. Criciúma se destacou pela especialização em máquinas agrícolas para todos os períodos, exceto 2006. Joinville também tinha uma plataforma de exportação diversa, apesar de ser marcada pelas vendas externas de bombas e compressores de ar. Blumenau e Chapecó têm cestas de exportação muito diversificadas que não obtiveram um terço de concentração em nenhum produto em específico.

O Rio Grande do Sul tem sua pauta de exportação da metal mecânica fortemente marcada pela presença de maquinário de usos diversos. Para Santa Rosa nos anos 2010, 2013 e 2016, Passo fundo e Não-me-Toque para 2006 e 2010, por exemplo, tiveram as vendas de máquinas agrícolas representando mais de $50 \%$ de sua pauta. A microrregião de Erechim tinha suas exportações concentradas em máquinas e equipamentos de funções específicas para o período de 2006 e 2010 e esteiras não mecanizadas para os demais períodos. Ijuí tinha suas exportações diversificadas, mas, com ênfase em elevadores e teleféricos para 2006 e máquinas e equipamentos com funções específicas nos demais períodos. A microrregião do Litoral Lagunas detinha valores exportados muito baixos até 2010, e, a partir de 2013 as exportações da indústria naval passaram a ocupar praticamente toda a pauta. As demais microrregiões, Caxias do Sul, Porto Alegre e Santa Cruz do Sul apresentaram pautas diversificadas, sendo que se pode levantar uma exceção para a última que teve uma pequena ênfase em metalurgia do ferro.

Por último, restam-se abordar as duas regiões goianas que representam o Centro Oeste do Brasil. A região de Goiânia detinha uma pauta diversificada para os anos de 2006 e 2010, passando para uma especialização de $66,03 \%$ em guindastes para 2013 e 85,00\% em metalurgia do ouro para 2016. Já a localidade de Catalão obteve uma especialização em metalurgia do ferro por ferroligas de metais compostos durante todos os períodos da análise.

\section{Considerações finais}

O artigo realizou uma descrição exaustiva das exportações das exportações do complexo metal mecânico brasileiro. Nota-se que os setores que compõem essa indústria não viveram o melhor momento dentro da economia brasileira com uma dificuldade grande para diversificar suas exportações tanto em nível dos destinos quanto ao nível dos produtos exportados.

Foi possível observar que o impulso das políticas públicas fizeram diferenças para o desenvolvimento das indústrias locais. Isso foi visto no papel que a Petrobrás realizou na compra de 
produtos da indústria naval e o desenvolvimento dessa indústria em periferias da economia brasileira como no Litoral Lagunar e em Suape. Isso levanta uma questão importante das oportunidades que ainda podem ser geradas nessa indústria via incentivos governamentais. O Brasil tem um potencial de navegabilidade extremamente alto e uma navegação de cabotagem praticamente a se desenvolver. Ademais, desde meados da década de 2000 a marinha brasileira vem desenvolvendo pesquisas no subsolo marinho que comprovam a riqueza econômica desse ambiente. Vidigal et all (2006), inclusive denominaram tal ambiente de Amazônia Azul por entender que há nela um potencial maior que na floresta equatorial. Dessa forma, seria importante manter a capacitação construída nesse setor com o intuito de solucionar problemas diversos da economia nacional.

Outro ponto interessante seria o desenvolvimento de políticas que tivessem como intuito elevar a posição de alguns locais em suas respectivas cadeias de valor. O caso de Vitória parece bem emblemático para esse problema já que a região tem uma forte capacidade em tratamentos básicos de ferro e poderia ser pensada alguma forma de ganhar espaços na produção de aços e outros produtos de mais alta sofisticação. Como essa região ainda não pertence ao polígono de concentração econômica brasileira, um programa de desenvolvimento local também contribuiria para a desconcentração industrial do país.

Por outro lado, o acirramento da competitividade internacional observado no último período levanta um alerta para a indústria como um todo e como poderia elaborar políticas para defender os vários setores estratégicos conjuntamente bem como suas cadeias de produção. O setor nacional de máquinas agrícolas se demonstrou bem estruturado e é um grande fornecedor para países da América Latina, assim como o setor automotivo. Entretanto, ambos vêm enfrentando a concorrência chinesa desde o início da década de 2010 e devem encontrar soluções para não perderem todo o mercado externo.

Assim, notou-se que apesar de todas as condições adversas encontradas pela indústria nacional nas últimas décadas, a metal mecânica continuou viva e manteve alguns mercados interessantes. A análise demonstrou que a pauta de exportação brasileira continua muito diversificada e um forte potencial de complementaridade regional. Enquanto se vê a metalurgia de Minas Gerais com capacidade de produção em competitividade internacional o mesmo pode ser dito para a indústria de máquinas e equipamentos agrícolas do Rio Grande do Sul. São Paulo ainda mantém uma indústria diversificada de vários tipos de transportes à máquinas e equipamentos para usos diversos. Ainda foi possível notar que alguns produtos nacionais detém mercado fácil a nível mundial e expressa a capacitação desenvolvida no país, como é o caso das aeronaves e tubos de metal de várias especificações.

\section{Bibliografia}

ALBUQUERQUE, E (EDITOR)., The role of institutional frameworks and local-global interaction in the emerging countries in the emergences and evolution of GINs. Ingineus - WP7., 2011

AMARAL, F.; FREITAS, F.; CASTILHO, M., Comércio internacional, especialização produtiva e competitividade: uma decomposição para o crescimento das exportações brasileiras entre 1995 e 2014, ANAIS..., II Encontro nacional de economia Industrial, Rio de Janeiro, 2017

BASTOS,C.; JORGE, C., O Ciclo brasileiro nos anos 2000 e as perspectivas macroeconômicas pós crise, Margenes, v.3, 2017

CIMOLI, M.; PORCILE, G.; SILVA, G. Reciprocidade implícita e crescimento na economia internacional: uma perspectiva estruturalista. Revista de economia política, v.32, nº2, p. 188-204, 2012

DINIZ, C.; Desenvolvimento poligonal no Brasil: nem desconcentração, nem contínua polarização. Nova Economia, v.3, nº 1,1993

FAJNZYLBER, F. A empresa Multinacional na industrialização da América Latina. In SERRA, J. América Latina: ensaios de interpretação econômica. Rio de Janeiro: Paz e Terra, 1979

HAUSMAN, R.; HWANG,J.; RODRICK,D., What you export matters. Working paper 11905 - National bureau of economic research, 2005

HIDALGO, C.; HAUSMANN, R.; The building blocks of economic complexity, Economic Development. v. 106, nº26. P. 10570-10575, 2009

HIDALGO, C.; et. all., The product space conditions the development of nations, Science. V. 307, p 482487. 2007 
KATZ, J.; A dinâmica do aprendizado tecnológico no período de substituição das importações e as recentes mudanças estruturais no setor industrial da Argentina, do Brasil e do México. In: KIN, L.; NELSON, R.; Tecnologia, aprendizado e inovação: as experiências das economias de industrialização recente, Editora da Unicamp, 2009.

KRUGMAN, P.; OBSTFELD, M.; MELITZ, M., Economia Internacional, Pearson, 2014

Lall, S. (2000): The Technological Structure and Performance of Developing Country Manufactured Exports, 1985-98, Oxford Development Studies. v. 28, pp. 337-369.

PEREZ, C., Finance and technical change: a long term view. African journal of science, technology, innovation and development. v.3, $\mathrm{n}^{\mathrm{o}} 1$, p. 10-35, 2011

PREBISCH, R.. O desenvolvimento Econômico da América latina e alguns de seus principais problemas; In: BIELSCHOWSKY, Ricardo. Cinquenta anos de pensamento da CEPAL, vol 1. Rio de Janeiro: Editora Record, 2000. cap 1, p. 69-136.

RIBEIRO, L. et al., Matrices of science and technology interactions and patterns of structured growth: implications for development. Scientometrics. v. 83, p. 55-75, 2010.

ROSENBERG, N.; Por dentro da Caixa Preta, Editora da Unicamp, 2009

SCHTEINGART, D.; Composición de las exportaciones, capacidades tecnológicas y desarrollo económico: ¿cuán determinante es el "qué” se exporta?, ANAIS..., XIII Jornadas de Economia Crítica, Rio Cuarto, 2015

THIRWALL, A. The Nature of economic growth. 1 ed Cheltenham: Edward Elgar, 2002

TREADO, C., Pittsburgh's Evolving Steel Legacy and the Steel Technology Cluster, Cambridge Journal of Regions, Economy and Society. n³, p. 105-120. 2010

VILAÇA, A., Underdevelopment in contemporary world: is structuralism still relevant?, Revista de economia política, v. 37, nº 4, p. 755-771, 2017

VIDIGAL, A. et. all., Amazônia Azul, Rio de Janeiro, Record, 2006

WOMACK, J. et. all., A máquina que mudou o mundo. Rio de Janeiro, Elsevier: Campus, 2004. 